\title{
Eco-Efficient Concrete Using Industrial Wastes: A Review
}

\author{
F.Pacheco-Torgal ${ }^{1, a}$, A. Shasavandi ${ }^{2, b}$, Said Jalali ${ }^{3, c}$ \\ ${ }^{123}$ Research Unit C-TAC, Sustainable Construction Group, University of Minho, \\ Guimarães, Portugal \\ atorgal@civil.uminho.pt, ${ }^{b}$ arman.sh@civil.uminho.pt, 'said@ civil.uminho.pt
}

Keywords: Eco-efficient concrete; sustainable construction; industrial wastes; Portland cement

\begin{abstract}
Concrete is one of the most widely used construction materials in the world. However, the production of Portland cement as the essential constituent of concrete requires a considerable energy level. Also releases a significant amount of chemical carbon dioxide emissions and other greenhouse gases (GHGs) into the atmosphere. Global demand will increase almost $200 \%$ by 2050 from 2010 levels. Thus, seeking an eco-efficient and sustainable concrete may be one of the main roles that the construction industry should play in sustainable construction.

Portland cement can be partially replaced by cementitious and pozzolanic materials, especially those of industry by-products such as fly ash, GGBS, silica fume, ceramic waste powder and metamorphic rock dust from stone cutting industry. The aggregates are also conserved by replacing them with recycled or waste materials (among which recycled concrete), ceramic waste, postconsumer glass, and recycled tires. All of the previous alternatives are, currently, the most used. This paper summarizes current knowledge about eco-efficient concrete, by reviewing previously published work.
\end{abstract}

\section{Introduction}

Concrete is the most used construction material on Earth, its consumption reaching almost 10.000 million tons per year [1]. The projections for the global demand of the main binder of concrete structures, Portland cement, show that in the next 40 years, concrete production will keep on rising [2]. China, for instance will need 40 billion square meters of combined residential and commercial floor space over the next 20 years which is equivalent to adding one New York city every two years or the area of Switzerland [3].

Portland cement production represents $74-81 \%$ of the total $\mathrm{CO}_{2}$ emissions of concrete, aggregates, in turn, represent $13-20 \%$ of the total, therefore batching, transport and placement activities have no relevant expression in terms of carbon dioxide emissions [4,5].

The production of one tonne of Portland cement generates 0.55 tonnes of chemical $\mathrm{CO}_{2}$ and requires an additional 0.39 tonnes of $\mathrm{CO}_{2}$ in fuel emissions for baking and grinding, all accounting for a total of 0.94 tonnes of $\mathrm{CO}_{2}$ [6]. Other authors [7] report that the cement industry emitted in 2000, on average, $0.87 \mathrm{~kg}$ of $\mathrm{CO}_{2}$ for every $\mathrm{kg}$ of cement produced. Josa et al. [8] used the 1992 CML methodology to assess the LCI of Portland cement produced in Holland, Switzerland, Sweden, Finland and Austria. The production of $1 \mathrm{~kg}$ of Portland cement can generate a maximum $800 \mathrm{~g}$ of $\mathrm{CO}_{2}$ in Type I cement. The same cement has $\mathrm{SO}_{2}$ and $\mathrm{NOx}$ emissions ranging from 1.1 to $3.4 \mathrm{~g}$ of equivalent $\mathrm{SO}_{2}$. However, a certain level of variability between different plants exists, Chen reports almost $20 \%$ variations for global warming [9].

Some authors suggest that the eco-efficiency of concrete could be made by the assessment of the amount of cement needed to generate a unit of compressive strength [10]. Daminelli et al. [11] suggest two indicators to measure the eco-efficiency of cement in concrete. The binder intensity (bi), that measures the amount $\left(\mathrm{kg} / \mathrm{m}^{3}\right)$ of binder to deliver $1 \mathrm{MPa}$ of compressive strength for concrete specimens with 28 days curing and the $\mathrm{CO}_{2}$ intensity index ( $c i$ ) that measures the amount $\left(\mathrm{kg} / \mathrm{m}^{3}\right)$ of carbon dioxide emissions to deliver $1 \mathrm{MPa}$ of compressive strength. The minimum values of $b i$ and ci are $5 \mathrm{~kg} / \mathrm{m}^{3} / \mathrm{MPa}$ and $1,5 \mathrm{~kg} / \mathrm{m}^{3} / \mathrm{MPa}$ respectively. 
Although concrete batching, transport and placement activities are responsible for very small amounts of the total concrete $\mathrm{CO}_{2}$ emissions, other environmental impacts must be considered. This is the case of the high water consumption involved in the washing of the ready-mixed concrete trucks. Between 700-1300 1 [12] of sludge water is needed, to in a single day, for each truck. Sludge water has a high level of solids and high alkalinity thus representing a hazardous waste [13]. These authors further state that concretes containing sludge water even present lower capillary water absorption. However, other authors [14] used sludge water and found higher reductions in compressive strength. Also, other factors can contribute to the eco-efficiency of concrete production as the choice of the mixing process [15].

Concrete has the ability to capture $\mathrm{CO}_{2}$ by a carbonation process. Although carbonation levels for current concrete structures are low, some authors found that after demolition they could almost double, going from 33\% to 59\% [16]. More recently, Collins [17] analyzed a concrete bridge with a primary life of 100 years showing that if carbonation is not considered in the LCA assessment, $\mathrm{CO}_{2}$ emissions of concrete can be overestimated by $13-48 \%$.

Since binder production represents the major part of the environmental impacts of concrete this means that investigations on binder replacement by pozzolanic additions or about eco-efficient binders would lead to an eco-efficient concrete. The durability of concrete structures plays also a major role in the eco-efficiency of concrete. In fact, current concrete structures presents higher permeability which allows water and other aggressive elements to enter. This leads to carbonation and chloride ion attack resulting in corrosion problems thus leading to expensive conservation actions or building new structures. Therefore, if we increase concrete durability from 50 to 500 years, we will reduce the environmental impact by a factor of 10 [18].

This manuscript carried out a literature review on investigations that contribute to the ecoefficiency of concrete, namely, partial replacement of cement by pozzolans and replacement of natural aggregates by non reactive wastes.

\section{Portland cement Concrete}

Concrete with pozzolans. The use of pozzolanic materials in construction dates back to thousands years ago. Roy [19] suggests that calcined clays mix with slaked lime (calcium hydroxide) were the first hydraulic binder made by men. Malinowsky [20] reports ancient constructions from 7000 B.C in the Galilei area (Israel) using this type of binder. The eruption of Thera in $1500 \mathrm{BC}$, which destroyed part of Santorini island, was responsible for the appearance of large amounts of ashes used by the Greeks to make mortars that revealed hydraulic properties. However, the Romans already knew that artificial pozzolans were needed to produce high performance mortars, so their use was not conditioned by the availability of natural pozzolans [21]. In reality, Roman mortars used for the Hadrian's wall in Britain were made of crushed ceramic material mixed with lime binder [22]. Crushed ceramics seem also to have been preferred from early Hellenistic to early Byzantine times in mortars related to water-bearing constructions and to protect the inside of walls from moisture (typically in baths, canals and aqueducts) [23]. However, the appearance of Portland cement in the XIX century, as it possesses a fast setting and higher early strength, was responsible for the decline of the use of lime-pozzolan binders. Despite recent advances in kiln design and alternative, low energy clinkers, it seems likely that the greatest carbon reduction within the industry are likely to be made by the inclusion of supplementary cementing materials [24].

Several standards define pozzolans as siliceous and aluminous materials which have very little or no cementitious characteristics but when finely divided, and in the presence of water, react with calcium hydroxide to form cementitious compounds [25]. The pozzolanic reactivity is a rather complex property which relies on the amorphous state of silica and aluminum, being higher with higher amorphous state. Generally speaking, the aluminosilicate species of the pozzolans will react with calcium hydroxide to form calcium silico aluminate phases. Pozzolans can be of natural origin or artificial, like calcined clays or industrial by-products. Natural pozzolans came from silicon rich magma that has solidified very rapidly thus remaining in an amorphous state. As to artificial pozzolans, they became structurally instable because of the hydroxyl groups left out due to the 
calcination. The pozzolanic activity of calcined clays is very much dependent of the loss of structural water which favors the creation of an amourphous structure. As to the pozzolanic industrial by-products such as fly ash or silica fume a similar process occurs since these materials have a very high content of silicon and aluminum [26]. Several pozzolan by-products are described below:

\section{Fly ash -FA}

Some supplementary cementitious material, like FA (a by-product from coal-fired electricity production), have very slow hydration characteristics thus providing very little contribution to early age strength [27]. FA is one the most used pozzolanic by-products, and although current replacement levels are below $40 \%$, some authors showed that it is feasible to use more than $50 \%$ [28] as cement replacement.

\section{Silica fume - SF}

$\mathrm{SF}$ is a by-product of the production of the silicon metal that possesses high pozzolanic activity. This by-product contributes for a denser concrete microstructure enhancing both strength and durability [29].

\section{Rice husk ash - RHA}

RHA is a highly reactive pozzolan obtained when rice husks are calcinated below the crystallization temperature, at $780{ }^{\circ} \mathrm{C}$. RHA based concrete has high strength and high durability performance [30]. Since each tonne of rice generates $40 \mathrm{~kg}$ of rice husk ash[31], this means that annual world rice production of almost 600 million tonnes can generate almost 20 million tones of RHA.

\section{Sewage sludge ash-SSA}

SSA is a siliceous material obtained by the calcination of water treatment wastes. Its pozzolanic activity depends on the chemical composition of the waste and the calcination temperature [32]. The production of sewage sludge from waste water treatment plants is increasing all over the world. This kind of sludge includes the solid material left from sewage treatment processes. The total production of sewage waste for the United States of America and the European Union approaches $17 \mathrm{Mt}$ of dry solids per year [33]. The expected growth of world population and also, the increase in the volume of waste water shows that sewage sludge ash will rise at a very fast pace in the next years.

\section{Waste ceramics and tungsten mine wastes}

Several authors already confirmed the pozzolanic reactivity of ceramic wastes [34].In Europe, the amount of wastes in the different production stages of the ceramic industry reaches some 3 to $7 \%$ of its global production. This means millions of tons of calcined-clays per year that can be used as Portland cement replacement. Some authors [35] show that tungsten mine waste is an aluminosilicate source with $\left(\mathrm{SiO}_{2}+\mathrm{Al}_{2} \mathrm{O}_{3}+\mathrm{Fe}_{2} \mathrm{O}_{3}\right)>70 \%$ presenting pozzolanic properties when submitted to a thermal treatment.

\section{Recycled glass-RG}

Finely ground waste glass having a particle size finer than $38 \mu \mathrm{m}$ has pozzolanic behavior, furthermore concrete containing ground glass exhibits a higher strength at both early and late ages compared to fly ash concrete. Dyer \& Dhir [36] refer that the high sodium content of the material raises concerns about whether the release of this element could ultimately exacerbate alkali-silica reaction (ASR). They also show that powdered container glass is not suitable for controlling alkalisilica reaction.

\section{Fluidized bed cracking catalyst - FBCC}

Catalysts are widely used in the petrochemical industry. Usually, when the catalytic properties of this product are degraded, the deactivated catalyst must be replaced. Some authors [37] showed that FBCC (a waste from the petrochemical industry) is a zeolite material containing more than 50\% $\mathrm{SiO}_{2}$ and about $40 \% \mathrm{Al}_{2} \mathrm{O}_{3}$. This material improves concrete strength and increases its durability [38].

\section{Non reactive wastes as aggregate replacement}

Although the use of construction and demolition wastes (C\&DW) for the replacement of natural aggregates has been studied for almost 50 years, today we still see that too many structures are made with raw aggregates. The reasons for that rely in the low cost of raw aggregates, the lack of 
incentives or the existence of low deposition costs and even, sometimes the lack of technical regulations. Recycled aggregates manufactured in laboratory are not contaminated with other wastes contrary to what happens with aggregates obtained from C\&DW. Corinaldesi \& Moriconi [39] showed that is possible to use $100 \%$ recycled aggregates without compressive strength loss as long as fly ash or silica fume are also used with a $\mathrm{W} / \mathrm{C}=0.4$.

Vegetable wastes. Several authors [40] used pine wastes to produce lightweight concrete. The wood waste particles have a dimension between $5 \mathrm{~mm}$ to $10 \mathrm{~mm}$ and have previously been immersed in sodium silicate. This treatment increases the adhesion between the waste and the cement paste and also, prevents the attack from insects or fungi.

Tyre rubber wastes. An estimated 1000 million tyres reach the end of their useful lives every year [41]. At present, enormous quantities of tyres are already stockpiled (whole tyre) or landfilled (shredded tyre), 3000 millions inside EU and 1000 millions in the US [42]. Waste tyres disposal areas contribute to the reduction of biodiversity, furthermore, the tyres hold toxic and soluble components [43]. The implementation of the Lanfill Directive 1999/31/EC [44] and the End of Life Vehicle Directive 2000/53/EC [45] banned the landfill disposal of waste tyres creating the driving force behind the recycling of these wastes. In the last years several authors investigated the replacement of natural aggregates by rubber aggregates. Rubber aggregates are obtained from waste tyres using two different technologies: mechanical grinding at ambient temperature or cryogenic grinding at a temperature below the glass transition temperature [46]. The first method generates chipped rubber for coarse aggregates replacement. As for the second method, it usually produces crumb rubber [47] to replace fine aggregates. Guneyisi et al. [48] mentioned that the strength of concretes containing silica fume, crumb rubber and tyre chips decreases with rubber content. These authors suggest that it is possible to produce a $40 \mathrm{MPa}$ concrete replacing a volume of $15 \%$ of aggregates by rubber waste.

PET wastes. These wastes represent one of the most common plastics that can be found in solid urban waste. In 2007 the world's annual consumption represented 250.000 million terephthalate bottles (10 million tons of waste) with a growth increase of $15 \%$. In the United States 50.000 million bottles are landfilled each year. Since PET waste is not biodegradable, it can remain in nature for hundreds of years [49]. Choi et al. [50] mentioned that the replacement of fine aggregates for treated PET/GBFS aggregates $(5-15 \mathrm{~mm})$ leads to a decrease in the compressive strength. For a $25 \%$ replacement, the mixtures with a $\mathrm{W} / \mathrm{C}=0.45$ and 3 curing days lost just $6.4 \%$ in compressive strength. For 28 curing days the compressive strength loss reaches just $9,1 \%$. Increasing the replacement percentage increases compressive strength loss but not in a proportional manner, for instance, for a $75 \%$ replacement the mixtures with a $\mathrm{W} / \mathrm{B}=0.45$ and 3 curing days lost just $16.5 \%$ in compressive strength. This means that these treated PET aggregates perform in almost a similar way as natural aggregates.

\section{Conclusions}

Portland cement production represents the majority of total $\mathrm{CO}_{2}$ emissions of concrete so the use of pozzolans as cement replacement can allow major carbon dioxide reductions and also increase the service life of concrete structures, furthermore, in the case of waste pozzolans it also reduces the disposal areas. New investigations are needed in order to maximize the volume of pozzolans used by the construction industry. Research is also needed about the synergetic effect between different pozzolans. As to the aggregates, which represent $13-20 \%$ of carbon dioxide emissions they can be replaced by several non reactive wastes.

\section{References}

[1] M. Glavind, Sustainability of cement, concrete and cement replacement materials in construction. In Sustainability of Construction Materials, Ed. Khatib, WoodHead Publishing in Materials, Great Abington, Cambridge, UK, 2009, pp.120-147.

[2] M.Taylor, D. Gielen, Energy efficiency and $\mathrm{CO}_{2}$ emissions from the global cement industry. International Energy Agency, 2006.

[3] R. Dobbs, Prime numbers: Megacities. Foreign Policy (2010) 
[4] D. Flower, J. Sanjayan, Green house gas emissions due to concrete manufacture, International Journal of Life Cycle Assessment 12 (2007) 282-288.

[5] D. Huntzinger, T. Eatmon, A life-cycle assessment of Portland cement manufacturing: comparing the traditional process with alternative technologies, Journal of Cleaner Production 17 (2009) 668-675.

[6] E. Gartner, Industrially interesting approaches to low- $\mathrm{CO}^{2}$ cements, Cement and Concrete Research 34 (2004)1489-1498.

[7] J. Damtoft, J.Lukasik, D.Herfort, D. Sorrentino, E.Gartner, Sustainable development and climate change initiatives, Cement and Concrete Research 38 (2008) 115-127.

[8] A. Josa, A. Aguado, A. Cardim, E. Byars, Comparative analysis of the life cycle impact assessment of available cement inventories in the EU, Cement and Concrete Research 37 (2007) 781-788.

[9] C. Chen, G. Habert, Y. Bouzidi, A. Julien, Environmental impact of cement production: detail of the different processes and cement plant variability evaluation, Journal of Cleaner Production 18 (2010) 478-485.

[10] S. Popovics, Analysis of the concrete strength versus water-cement ratio relationship, ACI Materials Journal 87 (1990) 517-29.

[11] B. Damineli, F. Kemeid, P. Aguiar, V. John, Measuring the eco-efficiency of cement use. Cement \& Concrete Composites 32 (2010) 555-562.

[12] F. Sandrolini, E. Franzoni, Waste wash water recycling in ready-mixed concrete plants, Cement and Concrete Research 31 (2001) 485-489.

[13] S. Tsimas, M.Zervaki, Reuse of waste water from ready-mixed concrete plants, Management of Environmental Quality 22 (2001) 7-17.

[14] B.Chatveera, P.Lertwattanaruk, Use of ready-mixed concrete plant sludge water in concrete containing an additive or admixture, Journal of Environmental Management 90 (2009) 19011908.

[15] B. Cazacliu, A. Ventura, Technical and environmental effects of concrete production: dry batch versus central mixed plant, Journal of Cleaner Production 18 (2010) 1320-1327.

[16] C. Pade, M. Guimaraes, The $\mathrm{CO}_{2}$ uptake of concrete in a 100 year perspective, Cement and Concrete Research 37 (2007) 1348-1356.

[17] F. Collins, Inclusion of carbonation during the life cycle of built and recycled concrete: Influence on their carbon footprint, International Journal of Life Cycle Assessment 15 (2010) 549-556.

[18] E. Mora, Life cycle, sustainability and the transcendent quality of building materials, Building and Environment 42 (2007) 1329-1334.

[19] D. Roy, C. Langton, Studies of ancient concretes as analogs of cementituos sealing materials for repository in Tuff. L A- 11527-MS, Los Alamos Nacional Laboratory (1989)

[20] R. Malinowsky, Prehistory of concrete. Concrete International 13 (1991) 62-68.

[21] P. Hazra, V. Krishnaswamy, Natural pozzolans in India, their utility, distribution and petrogragraphy, Records of the geological survey of India 87 (1987) 675-706.

[22] A. Guleç, A.Tulun, Physico-chemical and petrographical studies of old mortars and plasters of Anatolia, Cement and Concrete Research 27 (1997) 227 - 234.

[23] P. Degryse, J. Elsen, M.Waelkens, Study of ancient mortars from Sagalassos (Turkey) in view of their conservation, Cement and Concrete Research 21 (2002) $1457-1463$.

[24] M. Tyrer, C. Cheeseman, R. Greaves, P. Claisse, E. Ganjian, M. Kay, J. Churchman-Davies Potential for carbon dioxide reduction from cement industry through increased use of industrial pozzolans, Advances in Applied Ceramics 109 (2010) 275-279.

[25] Portuguese Standard NP 4220, Pozzolans for concrete, mortars and grout, The Portuguese Institute for Quality (2010)

[26] S. Agarwal, Pozzolanic activity of various siliceous materials, Cement and Concrete Research 36 (2006) 1735-1739. 
[27] A. Boukni, R. Swamy, A. Bali, Durability properties of containing $50 \%$ and $65 \%$ slag, Construction and Building Materials 23 (2009) 2836-2845.

[28] P. Van Heede, E. Gruyaerta, N. De Belie, Transport properties of high-volume fly ash concrete: Capillary water sorption, water sorption under vacuum and gas permeability, Cement and Concrete Composites 32 (2010) 749-756.

[29] H. Song, S. Pack, S. Nam, J. Jang, V. Saraswathy, Estimation of the permeability of silica fume cement concrete, Construction and Building Materials 24 (2010) 315-321.

[30] M. Zain, M. Islam, F. Mahmud, M. Jamil, Production of rice husk ash for use in concrete as a supplementary cementitious material, Construction and Building Materials 25 (2011) 798-805.

[31] R. Zerbino, G. Giaccio, G. Isaia, Concrete incorporating rice-husk ash without processing, Construction and Building Materials 25 (2011) 371-378.

[32] S. Pan, D. Tseng, C. Lee, Use of sewage sludge ash as fine aggregate and pozzolan in portland cement mortar, Journal of Solid Waste Technology and Management 28 (2002) 121-130.

[33] EUROSTAT, information on http://epp.eurostat.cec.eu.int (2005)

[34] F. Pacheco-Torgal; S. Jalali, Reusing ceramic wastes in concrete, Construction and Building Materials 24 (2010) 832-838.

[35] F. Pacheco-Torgal; J. Gomes, S. Jalali, Tungsten mine waste geopolymeric binders, Preliminary hydration products, Construction and Building Materials 23 (2009) 200-209.

[36] T. Dyer, R. Dhir, Evaluation of powdered glass cullet as a means of controlling harmful alkali-silica reaction, Magazine of Concrete Research 62 (2010) 749-759.

[37] M. Bukowska, B. Pacewska, I. Wilińska, Corrosion resistance of cement mortars containing spent catalyst of fluidized bed cracking (FBCC) as an additive, Journal of Thermal Analysis and Calorimetry 74 (2003) 931-942.

[38] N. Castellanos, J. Agredo, Using spent fluid catalytic cracking (FCC) catalyst as pozzolanic addition - A review, Ingenieria e Investigacion 30 (2010) 35-42.

[39] V. Corinaldesi, G. Moriconi, Influence of mineral additions on the performance of $100 \%$ recycled aggregate concrete. Construction and Building Materials 23 (2009) 2869-2876.

[40] P. Coatanlem, R. Jauberthie, F. Rendell, Lightweight wood chipping concrete durability, Construction and Building Materials 20 (2006) 776-781.

[41] World Bussiness Council for Sustainable Development - WBCSD, End-of-life tyres: A framework for effective management systems (2010).

[42] N. Oikonomou, S. Mavridou, The use of waste tyre rubber in civil engineering works, In Sustainability of construction materials Ed. J., Khatib, ISBN 978-1-84569-349-7, WoodHead Publishing Limited, Abington Hall, Cambridge, UK, 2009.

[43] K. Day, K. Holtze, J. Metcalfe, C. Bishop, B. Dutka, Toxicity of leachate from automobile tyres to aquatic biota, Chemosphere 27 (1993) 665-675.

[44] European Commission. Council directive 1999/31/EC of 26 April 1999 on the landfill of waste. Official Journal of the European Communities, L182, pp.1-19, 1999.

[45] European Commission. Directive 2000/76/EC of the European Parliament and of the Council of 4 December 2000 on incineration of waste. Official Journal of the European Communities, L332, pp.91-111, 2000.

[46] K. Nagdi, Rubber as an engineering material: Guidelines for user. Hanser Publication (1993).

[47] W. Eleazer, M. Barlaz, D. Whittle, Resource recovery alternatives for waste tires in North Carolina. School of Engineering, Civil Engineering Department, NCSU, US, 1992.

[48] E. Guneyisi, M. Gesoglu, T. Ozturan, Properties of rubberized concretes containing silica fume, Journal of Cement and Concrete Research 34 (2004) 2309-2317.

[49] D. Mello, S. Pezzin, S.vAmico, The effect of post consumer PET particles on the performance of flexible polyurethane foams, Polymer Testing 28 (2009) 702-708.

[50] Y. Choi, D. Moon, J. Chung, S. Cho, Effects of waste PET bottles aggregate on the properties of concrete, Cement and Concrete Research 35 (2005) 776-781. 